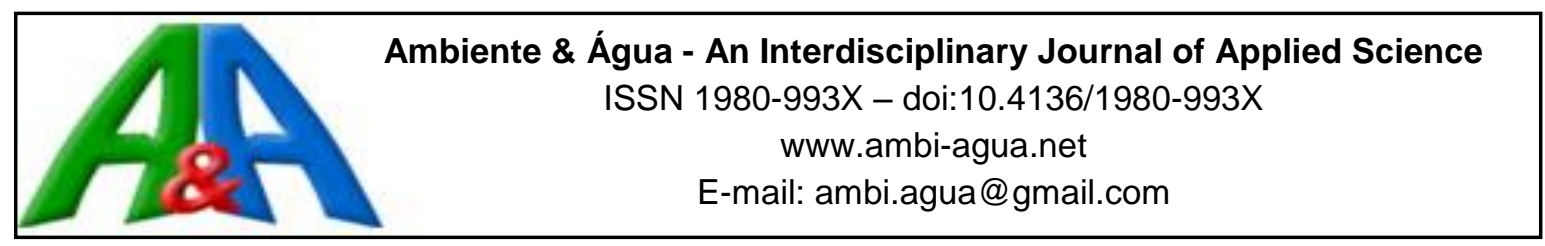

\title{
Contents of macronutrients and growth of 'BRS Marataoã' cowpea fertigated with yellow water and cassava wastewater
}

\author{
ARTICLES doi:10.4136/ambi-agua.2309
}

Received: 26 Jul. 2018; Accepted: 11 Mar. 2019

\section{Narcísio Cabral de Araújo ${ }^{1 *(D)}$; Vera Lucia Antunes Lima² ${ }^{(D}$; Jailton Garcia Ramos ${ }^{2}$ iD; Elysson Marcks Gonçalves Andrade ${ }^{2}$; Geovani Soares de $\operatorname{Lima}^{3}$; Suenildo Jósemo Costa Oliveira ${ }^{4}{ }^{\complement}$}

\author{
${ }^{1}$ Universidade Federal do Sul da Bahia (UFSB), Itabuna, BA, Brasil \\ Centro de Formação em Tecno-ciências e Inovação (CFTCI). E-mail: narcisioaraujo@gmail.com \\ ${ }^{2}$ Universidade Federal de Campina Grande (UFCG), Campina Grande, PB, Brasil \\ Unidade Acadêmica de Engenharia Agrícola (CTRN). E-mail: antuneslima@gmail.com, \\ jailtonbiossistemas@gmail.com, elyssonmarcks@yahoo.com.br \\ ${ }^{3}$ Universidade Federal de Campina Grande (UFCG), Pombal, PB, Brasil \\ Unidade Acadêmica de Ciências Agrárias (UAGRA). E-mail: geovani.soares@pq.cnpq.br \\ ${ }^{4}$ Universidade Estadual da Paraíba (UEPB), Lagoa Seca, PB, Brasil \\ Centro de Ciências Agrárias e Ambientais (CCAA). E-mail: suenildo@ ccaa.uepb.edu.br \\ "Corresponding author
}

\begin{abstract}
Agricultural utilization of yellow waters associated with cassava wastewater is a sustainable technique, since it allows reduction of costs related to acquisition of industrialized fertilizers and minimizes the environmental pollution caused by the inadequate disposal of these effluents. In this context, this study evaluated the macronutrient macronutrient content and growth of cowpea fertigated with yellow water associated with cassava wastewater and NPK as source of nutrients. The experiment was set up in a greenhouse located at Campus I of the Federal University of Campina Grande. The experimental design was completely randomized, composed of five treatments characterized by: fertigation with mineral fertilizers, in the form of NPK; organic fertigation composed of human urine, cassava wastewater, human urine plus cassava wastewater; and organo-mineral fertigation composed of urine, cassava wastewater and mineral phosphorus, with four replicates. At 36 days after sowing, the following parameters were determined: contents of nitrogen, phosphorus, potassium, sulfur and the variables number of leaves, plant height, stem diameter, leaf area, shoot fresh matter and shoot dry matter. The use of yellow waters promotes significant increases for growth and production variables for nitrogen and potassium contents mainly, as well as for growth and production variables. The contents of nitrogen, phosphorus and potassium were higher than the levels considered as adequate for the cowpea crop. The use of human urine and cassava wastewater have potential to meet the needs for the main macronutrients required by cowpea and the irrigation via fertigation with these biofertilizers positively influences the development of cowpea.
\end{abstract}

Keywords: agricultural use of wastes, human urine, vigna unguiculata (L.) Walp.

This is an Open Access article distributed under the terms of the Creative Commons Attribution License, which permits unrestricted use, distribution, and reproduction in any medium, provided the original work is properly cited. 


\section{Teores de macronutrientes e crescimento do feijão vigna 'BRS Marataoã' fertirrigado com água amarela e manipueira}

\section{RESUMO}

O uso agrícola de águas amarelas associadas à manipueira é uma técnica sustentável, uma vez que possibilita a redução de custos com a aquisição de fertilizantes industrializados e minimiza a poluição ambiental ocasionada pela destinação final inadequada desses efluentes. Neste contexto, objetivou-se com este trabalho avaliar os teores de macronutrientes e o crescimento do feijão vigna fertirrigado com águas amarela associada à manipueira e NPK como fonte de nutrientes. O experimento foi instalado em uma casa de vegetação localizada no Campus I da Universidade Federal de Campina Grande. Utilizou-se delineamento inteiramente casualizado composto por cinco tratamentos caracterizados por fertirrigações com fertilizantes minerais, na forma de NPK; orgânicos compostos por urina humana, manipueira, urina humana mais manipueira e organomineral composto por urina, manipueira e fósforo mineral e quatro repetições. Aos 36 dias após a semeadura foram avaliados os teores de nitrogênio, fósforo, potássio, enxofre e as variáveis: número de folhas, altura de planta, diâmetro caulinar, área foliar, massa fresca e seca da parte aérea. O uso de águas amarelas promove incrementos significativos para os teores de nitrogênio e potássio principalmente, assim como para as variáveis de crescimento e produção. Os teores de nitrogênio, fósforo e potássio apresentam valores superiores aos considerados adequados para o cultivo do feijão vigna. $\mathrm{O}$ uso de urina humana e a manipueira apresentam potencialidade para suprir as necessidades dos principais macronutrientes requeridos pela cultura do feijão vigna e a irrigação via fertirrigação com estes biofertilizantes pode influenciar positivamente o desenvolvimento dessa cultura.

Palavras-chave: urina humana, uso agrícola de resíduos, Vigna unguiculata (L.) Walp.

\section{INTRODUCTION}

Cowpea (Vigna unguiculata (L.) Walp.), also known as 'feijão-fradinho', 'feijãomacassar' or 'feijão-de-corda', is a source of income and food for many regions, especially the Brazilian Northeast (Benett et al., 2013). In Brazil, cowpea has undergone great changes, in both the production sector, with expansion of its cultivation to other regions, and in the commercial sector, with the standardization of the best product, beginning of industrial processing and product entry in new markets in the country and abroad (Freire Filho et al., 2011).

The recycling of nutrients contained in biodegradable wastes is a sustainable technique because it minimizes the use of synthetic mineral fertilizers and the negative impacts resulting from lack of environmental management in the exploitation of natural resources to produce fertilizers and pollution of waters due to uncontrolled disposal of wastes in the environment.

The increased costs of mineral fertilizers and increasing environmental pollution make the use of organic wastes in agriculture an attractive alternative from an economic point of view, due to the cycling of C (carbon) and nutrients (Silva et al., 2010).

It is important to make it clear that yellow waters have high concentrations of nitrogen $(\mathrm{N})$, phosphorus $(\mathrm{P})$, potassium $(\mathrm{K})$ and sulfur $(\mathrm{S})$. Human urine has been used as a source of urea and cassava wastewater as a source of potassium since the concentration of these substitute mineral fertilizers (Ranasinghe et al., 2016).

According to Sousa et al. (2008), various studied based on the separation of urine and feces have been carried out. Urine separation can provide a "free" hygienic fertilizer which can be used in agriculture (Kvarnström et al., 2006). For Karak and Bhattacharyya (2011), urine is a 
highly valuable source of nutrients which has been used in agriculture since ancient times.

Another effluent with great potential for recycling of nutrients through agricultural reuse is cassava wastewater because, according to Conceição et al. (2013), like human urine it is rich in macro and micronutrients, and can be used as fertilizer.

Recently, several studies have been conducted to evaluate the agricultural use of human urine. Araújo et al. (2015b) studied the cultivation components of hydroponic green fodder of corn fertilized with human urine as source of nutrients. Santos Júnior et al. (2015) evaluated grain and phytomass production in millet irrigated with human urine associated with domestic effluent. Bonvin et al. (2015) studied $\mathrm{N}$ and $\mathrm{P}$ absorption by ryegrass fertilized with synthetic urine. Santos et al. (2016) tested the use of human urine as source of nutrients for Bermuda grass and Botto et al. (2017) evaluated the yield of castor bean, cultivar 'BRS Nordestina', fertilized with human urine.

The human urine is rich in nitrogen in the form of urea, and cassava wastewater is rich in potassium; their use in agricultural production can reduce the use of mineral fertilizers that salinize the soil and water, destroy aquatic and terrestrial life, and which, during the process of manufacture, release into the air and water dioxins,, which are highly carcinogenic substances.

The use of wastewater in agricultural production reduces the use of mineral fertilizers, which generate negative impacts for water bodies, soil, air, etc. This happens because of the use of mineral fertilizers. This negatively affects the process of production, releasing POP'S (Persistent Organic Pollutants), as the dioxins, element high carcinogenic and smooth air and hydric flow. Regarding cassava wastewater, in the last seven years studies have been published analyzing the fertilizer potential of this effluent (Santos et al., 2010; Schwengber et al., 2010; Araújo et al., 2012; 2015b; Duarte et al., 2012; Silva Junior et al., 2012; Barreto et al., 2013; 2014; Dantas et al., 2015; Leal et al., 2015; Pessuti et al., 2015). Based on the results obtained in the above-mentioned studies, the authors concluded that the agricultural use of human urine or cassava wastewater had positive effects on the variables of the crops analyzed.

Therefore, considering the lack of studies using yellow water and cassava wastewater in cowpea cultivation, the present study evaluated the contents of nitrogen $(\mathrm{N})$, phosphorus $(\mathrm{P})$, potassium (K) and sulfur (S) and the growth of Vigna unguiculata (L.) Walp., cultivar 'BRS Marataoã', fertigated with human urine combined with cassava wastewater as source of nutrients. These sources of organic fertilizer have little to no acquisition cost for small rural producers, and may increase production, particularly that based in family agricultural.

\section{MATERIAL AND METHODS}

The experiment was conducted in a greenhouse between November and December 2015, at Campus I of the Federal University of Campina Grande (UFCG), in the city of Campina Grande ( $7^{\circ} 13^{\prime} 50^{\prime}$ ' S, 35 $52^{\prime}$ '52” W, 551 m of altitude), Paraíba state, Brazil.

In the research environment, the experimental units consisted of $15-\mathrm{L}$ plastic pots distributed at spacing of $0.80 \mathrm{~m}$ between rows and $0.50 \mathrm{~m}$ within the row, supported by a base made of bricks.

Each pot was perforated at the bottom to insert a drain, that is, a 15-cm long hose with nominal diameter of $6 \mathrm{~mm}$, which was attached to a 2.0-L PET bottle to collect the drained effluent, allowing its recirculation in the original pot in order to reduce possible losses of nutrients leached by the excess of water volumes drained from irrigation. The pots were filled with a $0.50-\mathrm{kg}$ layer of crushed stone $\left(\mathrm{n}^{\circ} 0\right)$, covering the bottom, and a $15.0-\mathrm{kg}$ layer of a Eutrophic Regolithic Neosol with sandy loam texture, properly pounded to break up clods and sieved, from the rural area of the municipality of Esperança, PB. Its analysis showed the following results: $\mathrm{pH}\left(\mathrm{H}_{2} \mathrm{O}\right)=5.58 ; \mathrm{EC}=0.56 \mathrm{mmhos} \mathrm{cm}^{-1} ; \mathrm{Al}=0.00 \mathrm{cmolc} \mathrm{dm}^{-3}$; $\mathrm{Mg}=2.78 \mathrm{cmolc} \mathrm{dm}^{-3} ; \mathrm{Ca}=9.07 \mathrm{cmolc} \mathrm{dm}^{-3} ; \mathrm{K}=0.33 \mathrm{cmolc} \mathrm{dm}^{-3} ; \mathrm{Na}=1.64 \mathrm{cmolc} \mathrm{dm}^{-3}$; 
$\mathrm{P}=3.98 \mathrm{mg} \mathrm{dm}^{-3} ; \mathrm{S}=13.72 \mathrm{cmolc} \mathrm{dm}^{-3} ; \mathrm{OC}=1.70 \% ; \mathrm{OM}=2.93 \%$ and $\mathrm{d}=1.28 \mathrm{~g} \mathrm{~cm}^{-3}$.

After the pots were filled, irrigation was applied to bring the soil to field capacity. Then, holes were opened and sowing was carried out by planting five seeds of the cowpea cultivar 'BRS Marataoã' per pot. 10 days after sowing (DAS), thinning was performed to leave two seedlings per pot.

Irrigation water volumes were estimated individually for each experimental plot with 2-day intervals based on water balance (difference between the mean volumes applied and drained sufficient to maintain the soil at field capacity, plus $20 \%$, to meet water losses through evapotranspiration). The water used in irrigation was collected in the public supply network of Campina Grande, PB.

The experimental design was completely randomized, with four replicates and five treatments, totaling 20 experimental plots. Treatments consisted of fertigation with NPK (Treatment 1 - NPK); only human urine (Treatment 2 - U); only cassava wastewater (Treatment $3-\mathrm{W}$ ); human urine plus cassava wastewater (Treatment $4-\mathrm{U}+\mathrm{W}$ ) and human urine plus cassava wastewater plus phosphorus (Treatment $5-\mathrm{U}+\mathrm{W}+\mathrm{P}$ ). Mineral fertilizers consisted of urea $(45.9 \% \mathrm{~N})$, single superphosphate $\left(18.9 \% \mathrm{P}_{2} \mathrm{O}_{5}\right)$ and potassium chloride $\left(60 \% \mathrm{~K}_{2} \mathrm{O}\right)$.

Treatments 1 and 5, in 10 fertirrigation treatments, were applied differently, because human urine and cassava wastewater must be diluted to soften the toxic effects that these effluents can cause in plants. If the concentrations of effluents applied via fertirrigation exceed the recommended limited by $10 \%$, injuries may be caused to plants, such as burned leaves.

Fertigation began 10 days after sowing (DAS). Each plot received the equivalent of $100 \mathrm{mg} \mathrm{N} \mathrm{kg}{ }^{-1}$ of soil, $300 \mathrm{mg} \mathrm{P} \mathrm{kg}-1$ of soil and $150 \mathrm{mg} \mathrm{K} \mathrm{kg}^{-1}$ of soil, according to the recommendations of Novais et al. (1991).

The amounts of human urine and cassava wastewater applied in each plot were estimated based on the concentrations of nitrogen and potassium in the effluents (Table 1) and the dose recommended by Novais et al. (1991) (100 mg N kg $\mathrm{m}^{-1}$ of soil and $150 \mathrm{mg} \mathrm{K} \mathrm{kg}^{-1}$ of soil).

The pots that received human urine were treated with $224.95 \mathrm{~mL}$ of this effluent to supply the nitrogen required by the cultivar, and $561.93 \mathrm{~mL}$ of cassava wastewater to supply the necessary potassium. To complete fertilization, phosphorus of mineral origin was applied in a portion of $23.83 \mathrm{~g}$ of $\mathrm{P}_{2} \mathrm{O}_{5}$ per pot.

Table 1. Physicochemical characterization of human urine (U) and cassava wastewater (W) used in the experiment.

\begin{tabular}{lccccccccc}
\hline & \multicolumn{8}{c}{ Parameters } \\
\cline { 2 - 10 } Effluents & $\mathrm{TKN}$ & $\mathrm{NH}_{3}-\mathrm{N}$ & $\mathrm{NO}_{3}$ & ${\mathrm{P}-\mathrm{PO}_{4}^{-3}}^{-3}$ & $\mathrm{~K}$ & $\mathrm{Na}$ & $\mathrm{Ca}+\mathrm{Mg}$ & $\mathrm{pH}$ & $\mathrm{EC}$ \\
\cline { 2 - 9 } & & & $\mathrm{g} \mathrm{L}^{-1}$ & & & & - & $\mathrm{mS} \mathrm{cm}^{-1}$ \\
\hline $\mathrm{U}$ & 6.668 & 5.257 & 0.002 & 0.325 & 1.558 & 2.509 & 0.034 & 9.12 & 42.7 \\
$\mathrm{~W}$ & 1.199 & 0.336 & 0.019 & 0.338 & 4.004 & 0.096 & 2.800 & 3.75 & 11.75 \\
\hline
\end{tabular}

Note: TKN: Total Kjeldahl Nitrogen; $\mathrm{NH}_{3}-\mathrm{N}$ : Ammoniacal Nitrogen; $\mathrm{NO}_{3}$ : Nitrate; $\mathrm{P}-\mathrm{PO}_{4}{ }^{-3}$ : Soluble Orthophosphate; K: Potassium; Na: Sodium; $\mathrm{Ca}+\mathrm{Mg}$ : total hardness; $\mathrm{pH}$ : Hydrogen potential and EC: Electrical Conductivity.

For treatments containing mineral fertilizers (Treatments 1 and 5), fertigation was split into 3 portions and applied at 10,20 and 28 DAS. For treatments containing human urine (Treatment 2), cassava wastewater (Treatment 3 ) and human urine plus cassava wastewater (Treatments 4 and 5), fertigation was split into 10 portions and applied at 10, 12, 14, 16, 18, 20, 22, 24, 26 and 28 DAS.

Human urine was subjected to a treatment, which consisted of storage in a hermetically sealed 20-L plastic bucket for 60 days before being used. For cassava wastewater, the treatment 
consisted of anaerobic digestion for 90 days in a 85-L plastic bucket, with an empty space of $10 \mathrm{~cm}$ inside it. The lid of the bucket was attached to a hose with the other tip immersed in a container with water up to $10 \mathrm{~cm}$ in depth, to release the gases generated during the effluent bio-digestion.

Regarding the presence of xenobiotics, everyone carries these in their bodies from food, drink, etc.; so the concentrations of xenobiotics would vary depending on the food habits of the individuals. The human urine utilized was from men who do not smoke and do not take any type of controlled medicine.

In relation to the use of cassava wastewater and human urine, these effluents harm only minimally, because they are a source of organic nutrients, with an easy assimilation into soil and plants. Moreover the applications followed a recommended method of fertilization which does not cause nutritional stress in the crop or eutrophic alterations in the hydric bodies and soil.

After treatment, the effluents were analyzed according to the methodology recommended by the Standard Methods for Wastewater (APHA et al., 2005), and their parameters are presented in Table 1.

Human urine and cassava wastewater were submitted to pre-treatment to reduce the concentration of hydrocyanic acid in cassava wastewater and increase the $\mathrm{pH}$ of human urine to eliminate pathogenic microorganisms in the effluent.

It is known that treated cassava wastewater reduces $\mathrm{pH}( \pm 3.0)$, while human urine increases it $( \pm 9.0)$. In this way, the $\mathrm{pH}$ of the soil solution, in an interval between 5.5 and 6.5 , promotes high nutrient availability for plants (Malavolta et al., 1989).

At 36 days after sowing (DAS), a period in which plants were at a late vegetative stage and in early flowering, when they assimilate maximum quantities of nutrients, growth variables were evaluated: plant height $(\mathrm{PH}, \mathrm{cm})$, stem diameter $(\mathrm{SD}, \mathrm{mm})$, number of leaves (NL, leaves plant $\left.^{-1}\right)$, leaf area $\left(\mathrm{LA}, \mathrm{cm}^{2}\right)$, shoot fresh matter (SFM, g plant $\left.{ }^{-1}\right)$ and shoot dry matter (SDM, g plant $^{-1}$ ).

Plant height was determined using a tape measure graduated in centimeters from the collar to the apical bud. Stem diameter was measured using a digital caliper, graduated in millimeters, at approximately $2.0 \mathrm{~cm}$ from the collar. Number of leaves was determined by counting green leaves longer than $3.0 \mathrm{~cm}$, disregarding dry leaves, from the basal leaves to the last open leaf in the plant. Leaf area was estimated by the mathematical model proposed by Lima et al. (2008), which consists in the sums of midrib length (L) and maximum width (W) of each leaflet, according to Equation 1:

$$
L A=\sum\left(0.9915 \times(L \times W)^{0.9134}\right)
$$

Where: LA is the leaf area of the cultivar $\left(\mathrm{cm}^{2}\right)$; $\mathrm{W}$ is the maximum width of each leaflet $(\mathrm{cm})$; and $\mathrm{L}$ is the midrib length $(\mathrm{cm})$.

To determine shoot fresh matter, one plant from each plot was cut close to the soil and weighed on a precision analytical scale. After weighing, the plants were placed in paper bags previously identified and dried in an oven at a controlled temperature of $65^{\circ} \mathrm{C}$ for 72 hours to determine SDM.

After SDM determination, plants were ground in a Wiley-type mill and placed in identified packages to determine the contents of nitrogen $\left(\mathrm{N}, \mathrm{g} \mathrm{kg}^{-1}\right)$, phosphorus $\left(\mathrm{P}, \mathrm{g} \mathrm{kg}^{-1}\right)$, potassium $\left(\mathrm{K}, \mathrm{g} \mathrm{kg}^{-1}\right)$ and sulfur $\left(\mathrm{S}, \mathrm{mg} \mathrm{kg}^{-1}\right)$. These analyses were conducted following the methodology described by EMBRAPA (2009).

The results of the studied variables were subjected to analysis of variance and means were compared by Tukey test at a 0.05 probability level using the program ASSISTAT v. 7.7 Beta (Silva and Azevedo, 2016). 


\section{RESULTS AND DISCUSSION}

Based on the results presented in Table 2, the analysis of variance showed significant effect $(\mathrm{p}<0.01)$ on the contents of nitrogen $(\mathrm{N})$, phosphorus $(\mathrm{P})$ and sulfur $(\mathrm{S})$ and non-significant effect $(p>0.05)$ on the content of potassium $(K)$. Significant statistical difference was also found between the means of $\mathrm{N}, \mathrm{P}$ and $\mathrm{S}$.

Table 2. Summary of analysis of variance and mean contents of $\mathrm{N}\left(\mathrm{g} \mathrm{kg}^{-1}\right), \mathrm{P}\left(\mathrm{g} \mathrm{kg}^{-1}\right)$, $\mathrm{K}\left(\mathrm{g} \mathrm{kg}^{-1}\right)$ and $\mathrm{S}\left(\mathrm{mg} \mathrm{kg}^{-1}\right)$ in the shoot of cowpea fertigated with human urine and cassava wastewater.

\begin{tabular}{lccccc}
\hline \multirow{2}{*}{ SV } & \multicolumn{5}{c}{ Mean square } \\
\cline { 2 - 6 } & $\mathrm{DF}$ & $\mathrm{N}$ & $\mathrm{P}$ & $\mathrm{K}$ & $\mathrm{S}$ \\
\hline Treatments & 4 & $151.29567^{* *}$ & $6.46752^{* *}$ & $34.12312^{\text {ns }}$ & $2895.89787^{* *}$ \\
Residual & 15 & 4.63867 & 0.20291 & 13.75016 & 15.22620 \\
CV\% & - & 4.39 & 8.78 & 11.82 & 6.53 \\
\hline Treatments & \multicolumn{5}{c}{ Means } \\
\hline - (NPK) & $52.50 \mathrm{a}$ & $6.41 \mathrm{a}$ & $36.38 \mathrm{a}$ & $43.45 \mathrm{~cd}$ \\
2 - (U) & $52.50 \mathrm{a}$ & $4.27 \mathrm{~b}$ & $27.60 \mathrm{a}$ & $35.55 \mathrm{~d}$ \\
3 - (W) & $36.40 \mathrm{~b}$ & $4.27 \mathrm{~b}$ & $29.21 \mathrm{a}$ & $51.84 \mathrm{bc}$ \\
4 - (U+W) & $51.80 \mathrm{a}$ & $3.69 \mathrm{~b}$ & $31.15 \mathrm{a}$ & $54.19 \mathrm{~b}$ \\
5 - (U+W+P) & $52.27 \mathrm{a}$ & $6.99 \mathrm{a}$ & $32.56 \mathrm{a}$ & $113.76 \mathrm{a}$ \\
\hline
\end{tabular}

Note: SV - Source of variation; DF - Degrees of freedom; CV - Coefficient of variation; NPK - Nitrogen, phosphorus and potassium; U - Human urine; W Cassava wastewater; $\mathrm{U}+\mathrm{W}-$ Human urine plus cassava wastewater; $\mathrm{U}+\mathrm{W}+\mathrm{P}-$ Human urine plus cassava wastewater plus phosphorus; (ns, **, *) - Not significant, significant at 0.01 and 0.05 probability levels by $\mathrm{F}$ test; Means followed by the same letter in the column do not differ by Tukey test $(\mathrm{p}>0.05)$.

For $\mathrm{N}$ contents, the means of Treatment 3 (fertigation with cassava wastewater) were different, whereas the means of the other treatments did not differ from one another. The maximum mean of $\mathrm{N}$ was $52.5 \mathrm{~g} \mathrm{~kg}^{-1}$, obtained in plants fertigated with yellow water (Treatment $2-\mathrm{U}$ ) and with mineral fertilizers (Treatment $1-\mathrm{NPK}$ ). The minimum mean of $\mathrm{N}$ was $36.40 \mathrm{~g} \mathrm{~kg}^{-1}$, obtained in plants fertigated with only cassava wastewater (Treatment $3-\mathrm{W}$ ), but this value was still higher than the concentration range considered as adequate for common beans (30 to $35 \mathrm{~g} \mathrm{~kg}^{-1}$ ) (Fageria et al., 1996) and for cowpea $\left(19.7 \pm 1.3 \mathrm{~g} \mathrm{~kg}^{-1}\right.$ ) (Freire Filho et al., 2005).

The maximum mean of $\mathrm{P}$ was $6.99 \mathrm{~g} \mathrm{~kg}^{-1}$, obtained in plants fertigated with urine plus cassava wastewater associated with the mineral fertilizer $\mathrm{P}(5-\mathrm{U}+\mathrm{W}+\mathrm{P})$. This value did not differ statistically from that of the treatment with NPK fertigation (control; $6.41 \mathrm{~g} \mathrm{~kg}^{-1}$ ). The means of $\mathrm{P}$ also did not differ between Treatment 2 (fertigation with yellow water), 3 (fertigation with cassava wastewater) and 4 (fertigation with yellow water associated with cassava wastewater).

According to the results in Table 2, $\mathrm{N}$ and $\mathrm{P}$ contents obtained in the present study were higher than those found by Parry et al. (2008), who analyzed the contents of macronutrients in cowpea shoots in soil fertilized with two $\mathrm{P}$ doses and in different sowing periods and obtained maximum values of $24.5 \mathrm{~g} \mathrm{~kg}^{-1}$ and $1.7 \mathrm{~g} \mathrm{~kg}^{-1}$, respectively. Means of $\mathrm{K}$ did not differ statistically, and the maximum value $\left(36.38 \mathrm{~g} \mathrm{~kg}^{-1}\right)$ was obtained under fertigation with NPK.

Mean $\mathrm{S}$ contents were statistically different between treatments, and the maximum value was approximately $113.76 \mathrm{mg} \mathrm{kg}^{-1}$, obtained under fertigation with human urine associated with 
cassava wastewater and mineral fertilizer $(5-\mathrm{U}+\mathrm{W}+\mathrm{P})$. This value is within the range are considered as adequate for common beans according to EMBRAPA (2009), from 18 to $50 \mathrm{mg} \mathrm{kg}^{-1}$, and below the adequate value for cowpea, which is $1.5 \pm 0.4 \mathrm{~g} \mathrm{~kg}^{-1}$ according to Freire Filho et al. (2005).

Except for S contents, all treatments led to N, P and K contents considered as adequate for common beans (Fageria et al., 1996). For cowpea, Freire Filho et al. (2005) state that adequate $\mathrm{P}$ and $\mathrm{K}$ contents should be $1.4 \pm 0.3$ and $32.0 \pm 3.6 \mathrm{~g} \mathrm{~kg}^{-1}$, respectively. Thus, according to Table 2, all treatments met the needs for $\mathrm{N}$ and $\mathrm{P}$ by cowpea plants and Treatments 1 (1-NPK) and $5(5-\mathrm{U}+\mathrm{W}+\mathrm{P})$ also met the needs of $\mathrm{K}$, indicating that fertigation management was satisfactory in the present study for the cowpea crop.

In a study carried out by (Upreti et al., 2011) with different crops (onion, potatoes, wheat, radish, rice), using mineral (NPK) and organic fertilizations (human urine), and with distinct spaces, it was observed that human urine positively affected the evaluated crops.

According to the summary of analysis of variance (Table 3), there was significant statistical difference between treatments ( $\mathrm{p}$ < 0.05) for stem diameter (SD), shoot fresh matter (SFM) and shoot dry matter (SDM), whereas the other variables did not differ statistically between treatments, and these results corroborate those found in the literature. Pereira et al. (2013) studied the effects of three sources of organic fertilization (bovine manure, goat manure and earthworm humus) on cowpea and found no significant effect on number of leaves and plant height. Sousa et al. (2013) evaluated the effect of increasing doses of bovine biofertilizer on cowpea growth at 4 days after sowing and obtained significant statistical difference for stem diameter (SD) and shoot dry matter (SDM). Alves et al. (2009), studying the effects of increasing doses of biofertilizer obtained by whey fermentation and applied through fertigation in cowpea, found significant effect on plant height and number of leaves and non-significant effect on stem diameter.

Table 3. Summary of analysis of variance and means for number of leaves per plant (NL, leaves plant $\left.^{-1}\right)$, plant height $(\mathrm{PH}, \mathrm{cm})$, stem diameter $(\mathrm{SD}, \mathrm{mm})$, leaf area $\left(\mathrm{LA}, \mathrm{cm}^{2}\right)$, shoot fresh matter (SFM, $\mathrm{g}_{\text {plant }}{ }^{-1}$ ) and shoot dry matter (SDM, g plant ${ }^{-1}$ ) of cowpea fertigated with human urine and cassava wastewater.

\begin{tabular}{lccccccc}
\hline \multirow{2}{*}{ SV } & \multicolumn{7}{c}{ Mean Square } \\
\cline { 2 - 8 } & DF & NL & PH & SD & LA & SFM & SDM \\
\hline Treatments & 4 & $4.55000^{\text {ns }}$ & $39.59375^{\text {ns }}$ & $1.21923^{*}$ & $10136.66698^{\text {ns }}$ & $130.99785^{*}$ & $2.01556^{*}$ \\
Residual & 15 & 5.65000 & 13.03750 & 0.26424 & 18187.72725 & 29.37111 & 0.49281 \\
CV\% & - & 12.81 & 10.82 & 6.18 & 16.00 & 11.45 & 10.54 \\
\hline Treatments & \multicolumn{7}{c}{ Means } \\
\hline 1 - (NPK) & $17.00 \mathrm{a}$ & $28.87 \mathrm{~b}$ & $7.95 \mathrm{ab}$ & $802.24 \mathrm{a}$ & $47.88 \mathrm{ab}$ & $6.96 \mathrm{ab}$ \\
- (U) & $18.75 \mathrm{a}$ & $37.50 \mathrm{a}$ & $8.78 \mathrm{a}$ & $874.18 \mathrm{a}$ & $47.7 \mathrm{ab}$ & $6.69 \mathrm{ab}$ \\
3 - (W) & $18.00 \mathrm{a}$ & $32.37 \mathrm{ab}$ & $7.54 \mathrm{~b}$ & $860.66 \mathrm{a}$ & $41.85 \mathrm{~b}$ & $5.98 \mathrm{~b}$ \\
4 - (U+W) & $19.50 \mathrm{a}$ & $34.50 \mathrm{ab}$ & $8.80 \mathrm{a}$ & $898.96 \mathrm{a}$ & $56.34 \mathrm{a}$ & $7.67 \mathrm{a}$ \\
5 - (U+W+P) & $19.50 \mathrm{a}$ & $33.62 \mathrm{ab}$ & $8.50 \mathrm{ab}$ & $779.28 \mathrm{a}$ & $42.93 \mathrm{~b}$ & $6.00 \mathrm{~b}$ \\
\hline
\end{tabular}

Note: SV - Source of variation; DF - Degrees of freedom; CV - Coefficient of variation; NPK Nitrogen, phosphorus and potassium; $\mathrm{U}$ - Human urine; $\mathrm{W}$ - Cassava wastewater; $\mathrm{U}+\mathrm{W}$ - Human urine plus cassava wastewater; $\mathrm{U}+\mathrm{W}+\mathrm{P}-$ Human urine plus cassava wastewater plus phosphorus; ( ${ }^{\mathrm{ns}}$, $\left.{ }^{* * *}, *\right)$ - Not significant, significant at 0.01 and 0.05 probability levels by $\mathrm{F}$ test; Means followed by the same letter in the column do not differ by Tukey test $(\mathrm{p}>0.05)$.

Significant differences were observed for plant height (PH), stem diameter (SD), shoot fresh matter (SFM) and shoot dry matter (SDM).

No statistical difference was found in the means of number of leaves (NL) and leaf area 
(LA). Except for the Treatment $5(5-\mathrm{U}+\mathrm{W}+\mathrm{P})$ for leaf area, the means of number of leaves and leaf area in the other treatments $(2-\mathrm{U}, 3-\mathrm{W}, 4-\mathrm{U}+\mathrm{W}$ and $5-\mathrm{U}+\mathrm{W}+\mathrm{P})$ were higher than those in the control $(1-\mathrm{NPK})$. A probable explanation for that can be related to the supply of other nutrients contained in yellow water and cassava wastewater, which were available to be assimilated by cowpea plants.

The maximum mean of number of leaves was 19.50 leaves per plant, obtained under fertigation with yellow water associated with cassava wastewater $(4-\mathrm{U}+\mathrm{W})$ and these effluents associated with phosphorus $(5-\mathrm{U}+\mathrm{W}+\mathrm{P})$. Similar results were found by Silva et al. (2010), who obtained on average 20.50 leaves per plant of cowpea fertigated with $30 \mathrm{~L} \mathrm{ha}^{-1}$ day $^{-1}$ of bovine biofertilizer, at 45 days.

For plant height, it can be observed that there were no differences between the means of plants fertigated with only cassava wastewater $(3-\mathrm{W})$, yellow water associated with cassava wastewater $(4-\mathrm{U}+\mathrm{W})$ and these effluents associated with mineral phosphorus $(5-\mathrm{U}+\mathrm{W}+\mathrm{P})$. Minimum mean of PH $(28.87 \mathrm{~cm})$ was obtained with NPK fertigation, whereas maximum values $(34.50$ and $37.5 \mathrm{~cm})$ were found in plants fertigated with yellow water associated with cassava wastewater $(4-\mathrm{U}+\mathrm{W})$ and only yellow water $(3-\mathrm{U})$, respectively.

The means of stem diameter of plants fertigated with NPK and yellow water associated with cassava wastewater and these effluents associated with mineral $\mathrm{P}(5-\mathrm{U}+\mathrm{W}+\mathrm{P})$ did not differ statistically, and the same occurred with Treatments 2 (yellow water) and 4 (yellow water associated with cassava wastewater). The minimum mean $(7.54 \mathrm{~mm})$ was obtained in plants fertigated with cassava wastewater, whereas the maximum values of 8.78 and $8.80 \mathrm{~mm}$ were obtained with fertigation using yellow water $(2-\mathrm{U})$ and yellow water associated with cassava wastewater $(4-\mathrm{U}+\mathrm{W})$, respectively. Evaluating the effect of cassava wastewater applied by fertigation on cowpea, at 35 DAS, Schwengber et al. (2010) observed that the highest value of stem diameter $(2.99 \mathrm{~mm})$ was obtained with application of $100 \mathrm{~m}^{3} \mathrm{ha}^{-1}$. Cruz et al. (2014), evaluating cowpea at 40 days after emergence under application of $4.0 \mathrm{~L} \mathrm{~m}^{-1}$ of organic biofertilizer produced by accelerated biodegradation of wastes of coconut straw and inflorescences, neem tree pruning and cashew tree pruning, observed stem diameter of more than $6.0 \mathrm{~mm}$, which is lower than the value found in the present study.

For leaf area (LA), the maximum mean was $898.96 \mathrm{~cm}^{2}$, observed in plants fertigated with yellow water associated with cassava wastewater. Studying the growth of cowpea fertigated with wastewater, Rebouças et al. (2010) found maximum leaf area of $943.0 \mathrm{~cm}^{2}$, which is very close to that observed in the present study.

The values of shoot fresh matter (SFM) were statistically different between the treatments tested. Its minimum (41.85 $\left.\mathrm{g} \mathrm{plant}^{-1}\right)$ and maximum (56.34 $\left.\mathrm{g} \mathrm{plant}^{-1}\right)$ values were obtained in plants fertigated with cassava wastewater and with yellow water associated with cassava wastewater $(4-\mathrm{U}+\mathrm{W})$, respectively.

For shoot dry matter (SDM), there was a statistical difference between the means of Treatments 3 (cassava wastewater), 4 (yellow water associated with cassava wastewater) and 5 (yellow water associated with cassava wastewater and mineral $\mathrm{P}$ ), and the results were not significant for the Treatments 1 (NPK) and 2 (yellow water). Minimum and maximum means were 5.98 and 7.67 g plant $^{-1}$, obtained in plants fertigated with cassava wastewater $(3-\mathrm{W})$ and yellow water associated with cassava wastewater $(4-\mathrm{U}+\mathrm{W})$, respectively.

In a study by Messa et al. (2016) to determine the release of fertilizers in clay soil, it was observed that most of the fertilizers used in the study were released into the soil solution more quickly when at a pH between 4.0 to 5.5 .

There probably was influence of the $\mathrm{pH}$ of the soil solution; its fluctuation can determine the availability of nutrients for the plants.

Evaluating the use of bovine biofertilizer and treated wastewater in cowpea fertigation,

Rev. Ambient. Água vol. 14 n. 3, e2309 - Taubaté 2019 
Sousa et al. (2013) and Rebouças et al. (2010) obtained positive response with gains in shoot dry matter. Using bovine manure to fertilize cowpea at 35 days after planting, Bastos et al. (2012) found fresh shoot matter of $27.30 \mathrm{~g}$ per plant.

According to the data in Table 3, although there was no significant statistical difference between the means of number of leaves (NL), plant height (PH) and leaf area (LA), when plants were fertigated with wastewaters the values were higher than those of plants fertigated with chemical fertilizer formulated with NPK. In other words, the nutrients present in the yellow water and cassava wastewater caused positive effects on the cowpea crop. Except for the number of leaves and plant height, fertigation with yellow water associated with cassava wastewater led to maximum means for the variables SD, LA, SFM and SDM. A probable explanation is that the nutrients present in the yellow water and cassava wastewater were well assimilated by the plants, indicating great nutritional potential for the associated use of these effluents in agricultural cultivation.

The fact of effect variables promoted different results for the response variables; this action possibly can be associated with the fact of synergism or nutritional antagonism in the soil.

According to Fageria (2001), excess ions in the soil solution, such as potassium, which is an abundant nutrient in the cassava wastewater, can affect the absorption of other essential nutrients by plants, such as calcium, magnesium, zinc and manganese, due to the antagonism between potassium and these elements.

\section{CONCLUSIONS}

$\mathrm{N}, \mathrm{P}$ and $\mathrm{S}$ contents, stem diameter, shoot fresh matter and shoot dry matter of cowpea were influenced by the fertigation with yellow water, association between yellow water and cassava wastewater, and these effluents associated with the source of P;

Maximum contents of N, P, K and S were obtained by fertigation with NPK and human urine plus cassava wastewater associated with the mineral source of $\mathrm{P}$;

Human urine and cassava wastewater applied by fertigation have potential to meet the needs of the cowpea crop for N, P and K; and

Maximum means of most growth variables were obtained in plants fertilized with human urine associated with cassava wastewater.

\section{REFERENCES}

APHA; AWWA; WEF. Standard Methods for the examination of water and wastewater. 21st ed. Washington DC, 2005.

ALVES, S. V.; ALVES, S. S. V.; CAVAlCANTI, M. L. F.; DEMARTELAERE, A. C. F.; TEÓFILO, T. M. S. Desempenho produtivo do feijoeiro em função da aplicação de biofertilizante. Revista Verde de Agroecologia e Desenvolvimento Sustentável, v. 4, n. 2, p. 113-117, 2009.

ARAÚJO, N. C.; FERREIRA, T. C.; OLIVEIRA, S. J. C.; GONÇALVES, C. P.; ARAÚJO, F. A. C. Avaliação do uso de efluente de casas de farinha como fertilizante foliar na cultura do milho (Zea mays L.). Engenharia na Agricultura, v. 20, n .4, p. 340 - 349, 2012. http://dx.doi.org/10.13083/1414-3984.v20n04a06

ARAÚJO, N. C.; OLIVEIRA, S. J. C.; FERREIRA, T. C.; LIMA, V. L. A.; QUEIROZ, A. J. P.; ARAÚJO, F. A. C. Crescimento e Produtividade de Milho Fertilizado com Manipueira como Fonte Alternativa de Nutrientes. Tecnologia e Ciência Agropecuária, v. 9, n. 2, p. 31 - 35, 2015a. 
ARAÚJO, N. C.; COURA, M. A.; OLIVEIRA, R.; SABINO, C. M. B.; OLIVEIRA, S. J. C. Cultivo hidropônico de milho fertirrigado com urina humana como fonte alternativa de

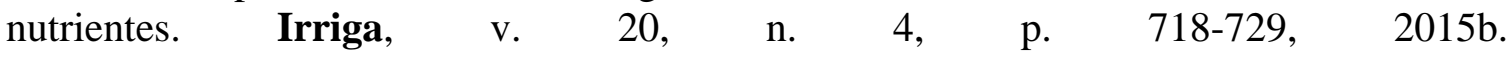
https://dx.doi.org/10.15809/irriga.2015v20n4p718

BARRETO, M. T. L.; ROLIM, M. M.; PEDROSA, E. M. R.; MAGAlHÃES, A. G.; TAVARES, U. E.; DUARTE, A. S. Atributos químicos de dois solos submetidos à aplicação de manipueira. Agrária - Revista Brasileira de Ciências Agrárias, v. 8, n. 4, p. 528-534, 2013. https://dx.doi.org/10.5039/agraria.v8i4a2425

BARRETO, M. T. L.; MAGALHÃES, A. G.; ROLIM, M. M.; PEDROSA, E. M. R.; DUARTE, A. S.; TAVARES, U. E. Desenvolvimento e acúmulo de macronutrientes em plantas de milho biofertilizadas com manipueira. Revista Brasileira de Engenharia Agrícola e Ambiental, v. 18, n. 5, p. 487-494, 2014. http://dx.doi.org/10.1590/S141543662014000500004

BASTOS, V. J.; MELO, D. A.; ALVES, J. M. A.; UCHÔA, S. C. P.; SILVA, P. M. C.; TEIXEIRA JUNIOR, D. L. Avaliação da fixação biológica de nitrogênio em feijão-caupi submetido a diferentes manejos da vegetação natural na savana de Roraima. Revista Agro@mbiente On-line, v. 6, n. 2, p. 133-139, 2012. http://dx.doi.org/10.18227/19828470ragro.v6i2.851

BENETT, C. G. S.; LIMA, M. F.; BENETT, K. S. S.; CAIONE, G.; PELLOSO, M. F. Formas de aplicação e doses de nitrogênio em cobertura na cultura do feijão-caupi. Revista Agrotecnologia, v. 4, n. 1, p. 17-30, 2013. https://dx.doi.org/10.12971/1449

BONVIN, C.; ETTER, B.; UDERT, K. M.; FROSSARD, E.; NANZER, S.; TAMBURINI, F.; OBERSON, A. Plant uptake of phosphorus and nitrogen recycled from synthetic sourceseparated urine. Ambio, v. 44, n. 2, p. 217-227, 2015. http://dx.doi.org/10.1007/s13280014-0616-6

BOTTO, M. P.; MUNIZ, L. F.; AQUINO, B.; SANTOS, A. B. Produtividade da mamona Cultivar BRS nordestina fertilizada com urina humana na agricultura de pequeno porte. Revista AIDIS de Ingeniería y Ciencias Ambientales: investigación, desarrollo y práctica, v. 10, n. 1, p. 113-124, 2017.

CONCEIÇÃO, A. A.; RÊGO, A. P. B.; SANTANA, H.; TEIXEIRA, I.; CORDEIRO MATIAS, A. G. C. Tratamento de efluentes resultantes do processamento da mandioca e seus principais usos. Revista Meio Ambiente e Sustentabilidade, v. 4, n. 2, p. 118-130, 2013.

CRUZ, J. S.; SOUSA, E. C.; BELTRÃO JÚNIOR, J. A.; ALMEIDA, J. M. U.; LUNA, N. S. Comportamento vegetativo do feijão caupi irrigado e adubado sob diferentes doses de biofertilizante orgânico. Revista Brasileira de Agricultura Irrigada, v. 8, n. 2, p. 154160, 2014. https://dx.doi.org/10.7127/rbai.v8n200241

DANTAS, M. S. M.; ROLIM, M. M.; DUARTE, A. S.; PEDROSA, E. M. R.; TABOSA, J. N.; DANTAS, D. C. Crescimento do girassol adubado com resíduo líquido do processamento de mandioca. Revista Brasileira de Engenharia Agrícola e Ambiental, v.19, n.4, p.350 357, 2015. http://dx.doi.org/10.1590/1807-1929/agriambi.v19n4p350-357

DUARTE, A. S.; SILVA, Ê. F. F.; ROLIM, M. M.; FERREIRA, R. F. A. L.; MALHEIROS, S. M. M.; ALBUQUERQUE, F. S. Uso de diferentes doses de manipueira na cultura da alface em substituição à adubação mineral. Revista Brasileira de Engenharia Agrícola e Ambiental, v. 16, n. 3, p. 262-267, 2012. 
EMBRAPA. Manual de análise química de solos, plantas e fertilizantes. 2. ed. Brasília, DF: Embrapa Informações Tecnológica, 2009, 627p.

FAGERIA, N. K.; OLIVEIRA, I. P.; DUTRA, L. G. Deficiências nutricionais na cultura do feijoeiro e suas correções. Goiânia: Embrapa-CNPAF-APA, 1996. 40 p. (Documentos, n. $65)$.

FAGERIA, V. D. Nutrient interactions in crop plants. Journal of plant nutrition, v. 24, n. 8, p. 1269-1290, 2001.

FREIRE FILHO, F. R.; LIMA, J. A. A.; RIBEIRO, V. Q. Feijão-caupi: Avanços tecnológicos. Brasília, DF: Embrapa Informações Tecnológicas, 2005. 519 p.

FREIRE FILHO, F. R.; RIBEIRO, V. Q.; ROCHA, M. M.; SILVA, K. J. D.; NOGUEIRA, M. S. R.; RODRIGUES, E. V. Feijão-caupi no Brasil: produção, melhoramento genético, avanços e desafios. Teresina: Embrapa Meio-Norte, 2011, 84 p.

KVARNSTRÖM, E.; EMILSSON, K.; STINTZING, A. R.; JOHANSSON, M.; JÖNSSON, H.; PETERSENS, E.; SCHÖNNING, C.; CHRISTENSEN, J.; HELLSTRÖM, D.; QVARNSTRÖM, L. RIDDERSTOLPE, P.; DRANGERT, JAN-O. Separação de urina: Um passo em direção ao saneamento sustentável. Estocolmo: Instituto Ambiental de Estocolmo, 2006. Available at: www.ecosanres.org. Access: 24 Jan. 2017.

KARAK, T.; BHATTACHARYYA, P. Human urine as a source of alternative natural fertilizer in agriculture: A flight of fancy or an achievable reality. Resources, Conservation and Recycling. v. 55, n. 4, p. $400-408,2011$.

LEAL, F. R. R.; LEAL, M. P. C.; ALBUQUERQUE, C. L. C. D. Avalição do efeito da manipueira em aplicação vias foliar e substrato na produção de coentro. Cadernos de Agroecologia, v. 10, n.3, 2015.

LIMA, C. J. G. S.; OLIVEIRA, F. A.; MEDEIROS, J. F.; OLIVEIRA, M. K. T.; FILHO, A. F. O.; Modelos matemáticos para estimativa de área foliar de feijão caupi. Revista Caatinga, v. 21, n. 1, p.120-127, 2008.

MALAVOlTA, E.; VITTI, G. C.; OLIVEIRA, A.S. Avaliação do estado nutricional das plantas: princípios e aplicações. Piracicaba: Associação Brasileira para Pesquisa da Potassa e do Fosfato, 1989. 201 p.

MESSA, L. L.; FROES, J. D.; SOUZA, C. F.; FAEZ, R. Chitosan-clay hybrid for encapsulation of fertilizers and release sustained of potassium nitrate fertilizer. Química Nova, v. 39, n. 10, p. 1215-1220, 2016.

NOVAIS, R. F.; NEVES, J. C. L.; BARROS, N. F. Ensaio em ambiente controlado. In: OLIVEIRA, A. J. (Ed.). Métodos de pesquisa em fertilidade do solo. Brasília: EmbrapaSEA p. 189-253, 1991.

PARRY, M. M.; KATO, M. S. A.; CARVALHO, J. G. Macronutrientes em caupi cultivado sob duas doses de fósforo em diferentes épocas de plantio. Revista Brasileira de Engenharia Agrícola e Ambiental, v. 12, n. 3, p. 236-242, 2008. http://dx.doi.org/10.1590/S141543662008000300003

PEREIRA, R. F; CAVAlCANTE, S. N.; LIMA, A. S.; MAIA FILHO, F. C. F.; SANTOS, J. G. R. Crescimento e rendimento de feijão vigna submetido à adubação orgânica. Revista Verde de Agroecologia e Desenvolvimento Sustentável, v. 8, n. 3, p. 91 - 96, 2013. 
PESSUTI, C. A. A.; HERMES, E.; NEVES, A. C.; SILVA, R. P.; PENACHIO, M. ZENATTI, D. C. Diferentes doses de biofertilizante proveniente da digestão anaeróbia de efluente de processamento de mandioca no cultivo de soja. Revista Gestão \& Sustentabilidade Ambiental, v. 4, p. 556-564, 2015.

RANASINGHE, E. S. S.; KARUNARATHNE, C. L. S. M.; BENERAGAMA, C. K.; WIJESOORIYA, B. G. G. Human urine as a low cost and effective nitrogen fertilizer for bean production. Procedia food science, v. 6, p. 279-282, 2016.

REBOUÇAS, J. R. L.; DIAS, N. S.; GONZAGA, M. I. S.; GHEYI, H. R.; SOUSA NETO, O. N. Crescimento do feijão-caupi irrigado com água residuária de esgoto doméstico tratado. Revista Caatinga, v. 23, n. 1, p. 97-102, 2010.

SANTOS, M. H. V.; ARAÚJO, A. C.; SANTOS, D. M. R.; LIMA, N. S.; LIMA, C. L. C.; SANTIAGO, A. D. Uso da manipueira como fonte de potássio na cultura da alface (Lactuca sativa L.) cultivada em casa-de-vegetação. Acta Scientiarum Agronomy, Maringá, v. 32, n. 4, p. 729-733, 2010. https://dx.doi.org/10.4025/actasciagron.v32i4.4819

SANTOS JÚNIOR, J. A.; SOUZA, C. F.; PÉREZ-MARIN, A. M.; CAVALCANTE, A. R.; MEDEIROS, S. S. Interação urina e efluente doméstico na produção do milheto cultivado em solos do semiárido paraibano. Revista Brasileira de Engenharia Agrícola e Ambiental, v. 19, n. 5, p. 456-463, 2015. https://dx.doi.org/10.1590/18071929/agriambi.v19n5p456-463

SANTOS, O. S. N.; TEIXEIRA, M. B.; QUEIROZ, L. M.; FADIGAS, F. S.; PAZ, V. P. S.; SILVA, A. J. P.; KIPERSTOK, A. Nitrogen recycling through fertilization of Bermuda grass using human urine diluted in water. Revista Brasileira de Agroecologia, v. 11, n. 3, p. 164-171, 2016.

SILVA, F. A. M.; VILAS-BOAS, R. L.; SILVA, R. B. Resposta da alface à adubação nitrogenada com diferentes compostos orgânicos em dois ciclos sucessivos. Acta $\begin{array}{llllll}\text { Scientiarum } & \text { Agronomy, } & \text { v. } & 32, & \text { p. }\end{array}$ https://dx.doi.org/10.4025/actasciagron.v32i1.1340

SILVA, F. A. S.; AZEVEDO, C. A. V. They assistat software version 7.7 and its use in the analysis of experimental data. African Journal of Agricultural Research, v. 11, n. 39, p. 3733 - 3740, 2016. https://dx.doi.org/10.5897/AJAR2016.11522

SILVA JUNIOR, J. J.; COELHO, E. F.; SANT’ANA, J. A. V.; SANTANA JUNIOR, E. B.; PAMPONET, A. J. M. Uso da manipueira na bananeira 'terra maranhão' e seus efeitos no solo e na produtividade. Irriga, v. 17, n. 3, p. 353 - 363, 2012.

SCHWENGBER, J. A. M.; SILVA, F. F.; SMIDERLE, O. J.; SCHWENGBER, D. R. Nodulação do feijão-caupi em função da aplicação de três águas de farinheira. Revista em Agronegócios e Meio Ambiente, v. 3, n. 2, p. 135-146, 2010.

SOUSA, J. T.; HENRIQUE, I. N.; LOPES, W. S.; LEITE, V. D. Gerenciamento Sustentável de Água Residuária Doméstica. Health and Environment Journal, v. 9, n. 1, 2008.

SOUSA, G. G.; SANTOS, E. M.; VIANA, T. V. A.; OLIVEIRA, C. M. B.; ALVINO, F. C. G.; AZEVEDO, B. M. Fertirrigação com biofertilizante bovino na cultura do feijoeiro. ACSA - Agropecuária Científica no Semi-Árido, v. 9, n. 4, p. 76 - 82, 2013.

UPRETI, H.; SHRESTHA, P.; PAUDEL, P. Effect of human urine as fertilizer on crop production. Agronomy Journal of Nepal, v. 2, p.168-172, 2011. 